\title{
RITKASÁGI MATROIDOKRÓL
}

\author{
MIHÁLYKÓ ANDRÁS
}

\begin{abstract}
Egy $G=(V, E)$ gráfot $(k, \ell)$-ritkának nevezünk, ha $i_{G}(X) \leq k|X|-\ell$ teljesül minden $|X| \geq 2$ csúcshalmazra, ahol $i_{G}(X)$ a $G$ gráf $X$ által feszített éleinek számát jelenti. Ezen ritkasági feltételek minden $k \in \mathbb{Z}_{+}$és $\ell<2 k$ egész mellett matroidot alkotnak a $G$ gráf élein. Ezek az úgynevezett ritkasági matroidok (count matroid). Ritkasági matroidok feltételei számos helyen megjelennek a kombinatorikus optimalizálásban, például a feszítőfáknál és párosításoknál, vagy a merevségelméletben. Célunk most a ritkasági matroidok részletesebb bemutatása a definícióktól néhány ismert eredményen keresztül egészen a nyitott problémákig.
\end{abstract}

\section{Bevezetés}

Gráfok ritkasági tulajdonságainak vizsgálata gyakori a gráfelméletben. Elég csak egy összefüggő gráf feszítőfájára gondolni, amit könnyen egy ritkasági tulajdonságként lehet felfogni. Tekintsük ugyanis a $G=(V, E)$ összefüggő gráf egy tetszőleges $(V, F)$ feszítőfáját. Ismert, hogy $|F|=|V|-1$, míg minden $X \subseteq V$ részhalmazra $i_{F}(X) \leq|X|-1$, ahol $i_{F}(X)$ az $X$ halmaz által feszített élek számát jelöli az $F$ élhalmazból. (Hasonló módon $i_{G}(X):=i_{E}(X)$.) Így tehát az $F$ feszítőfa élei „ritkák” a $G$ gráfban. Hasonló ritkasági feltételek több helyen is előfordulnak merevségelmélettől páros gráfok párosításáig. Célunk most ezeknek egy közös általánosítását bemutatni, aminek segítségével egységesen kezelhetjük ezen gráfokat. Ezen közös platformot az úgynevezett ritkasági matroidok (angolul count matroid) szolgáltatják.

A ritkasági matroidokat Lorea vezette be [12] és Whiteley általánosította 1986ban ([17, Appendix]). Azóta számos helyen felhasználták és több irányba is tovább általánosították őket. Például Frank irányított gráfokra bővítette ki a definíciót [5, 13.5 fejezet], amely általánosítás segítségével például egy súlyozott irányított gráf minimális költségü gyökeresen $k$-összefüggő részgráfját lehet megtalálni. A szimmetrikus merevség témaköréből kiindulva csoportelemekkel címkézett gráfokra általánosították a ritkasági matroidot ([8],[16], [18]).

Ritkasági matroidokra néhány olyan feladatot is meg tudunk oldani polinomiális időben, amelyek megoldásának bonyolultsága általános matroidokra nem ismert 
vagy NP-nehéz. Mivel a ritkasági matroidok számos speciális osztálya jól ismert és széles körben vizsgált, ez reményt adhat újabb problémák megoldásához, hiszen az ismert osztályokra használt ötletek esetleg kiterjeszthetők a teljes matroid családra.

Tekintsük például a következő egyszerü feladatot: adott egy $F$ feszítőfa, tegyük 2-él-összefüggővé minimális számú új él hozzáadásával. (Egy $G=(V, E)$ gráf 2-élösszefüggő, ha tetszőleges $e \in E$ élet törölve a gráfból $G-e$ továbbra is összefüggő marad.) Ennek alkalmazása lehet, ha például biztonságra törekszünk, és egy kapcsolat esetleges meghibásodása esetén is fenn akarjuk tartani a gráf összefüggőségét. A kérdés egyszerüen megválaszolható feszítőfára, de megmutatjuk, hogyan általánosodik egyéb ritkasági feltételekre, az úgynevezett redundánssá növelési feladat keretében.

A cikk első felében bevezetjük a ritkasági matroidokat, második felét a redundánssá növelési feladat bemutatásának szánjuk, végül néhány nyitott kérdést ismertetünk. A fejezet további részében a matroidokat definiáljuk, majd a 1.2. alfejezetben bemutatjuk a cikk további részében használt példákat. A 2. fejezetben a ritkasági matroidokat vezetjük be, részben Frank munkájára [5] támaszkodva, majd a 2.1. alfejezetben ezt kiterjesztjük hipergráfokra is. A 3. fejezetben a ritkasági matroidok redundáns növelését tárgyaljuk, amely eredmények szorosan kapcsolódnak Király és Mihálykó 2020-as cikkéhez [10]. A 4. fejezetben ritkasági matroidokkal kapcsolatos nyitott kérdéseket teszünk fel.

\subsection{Matroidok}

A matroidok a lineáris algebrából ismert lineáris függetlenség koncepcióját általánosítják. A kombinatorikus optimalizálás területén gyakran megjelennek és algoritmikus szempontból közkedveltek. Például mohó algoritmussal lehet rajtuk optimalizálni tetszőleges költségfüggvény mellett. Egy másik közismert eredmény az Edmonds-féle matroid metszet tétel [2], amely segítségével két matroid közös struktúráját vizsgálhatjuk algoritmikusan. A matroidokról és kapcsolatukról a szubmoduláris függvényekkel az olvasó részletes bevezetést talál Frank könyvében $[5]$.

1.1. Definíció. Adott egy $S$ alaphalmaz és részhalmazainak $\mathcal{F}$ rendszere. Az $(S, \mathcal{F})$ párt matroidnak nevezzük, ha a következő három axiómát teljesíti:

A1) $\emptyset \in \mathcal{F}$

A2) Ha $X \in \mathcal{F}$ és $Y \subset X$, akkor $Y \in \mathcal{F}$

A3) Minden $X \subseteq S$ részhalmazra az $\mathcal{F}$-nek $X$-ben fekvő, $X$-ben legbővebb tagjai azonos elemszámúak.

Ezen tulajdonságok az úgynevezett függetlenségi axiómák, az $\mathcal{F}$ elemei a független halmazok. Könnyü látni, hogy az A1), A2) és A3) feltételeket a lineárisan 
független halmazok rendszere teljesíti. Az A3) axióma lecserélhető a következő A3') axiómára, ekvivalens definíciót eredményezve [5]:

A3') $H a F_{1}, F_{2} \in \mathcal{F}$, és $\left|F_{1}\right|<\left|F_{2}\right|$, akkor létezik olyan $f \in F_{2}-F_{1}$, hogy $F_{1} \cup\{f\} \in$ $\mathcal{F}$.

A tartalmazásra nézve minimális nem független halmazokat köröknek nevezzük.

\subsection{Példák}

Matroidok gyakran előfordulnak gráfelméleti kontextusban. Három közismert példát hozunk, amelyek - mint később kiderül - mind ritkasági matroidok speciális esetei.

Grafikus matroid Legyen $G$ egy irányítatlan gráf, és legyen $\mathcal{F}$ a $G$-beli erdők éleinek családja. Könnyen látható, hogy ezek a $G$ élein mint alaphalmazon teljesítik a függetlenségi axiómákat. Az így kapott matroidot grafikus matroidnak nevezzük. Ha $G$ összefüggő, akkor a maximális független halmazok éppen a feszítőfák élei.

Transzverzális matroid Tekintsük a $G=(S, T, E)$ páros gráfot. Egy $I \subseteq S$ részhalmazt párosíthatónak nevezünk, ha létezik olyan párosítás $G$-ben, amely fedi az $I$ elemeit. Legyen $\mathcal{I}$ az $S$ párosítható részhalmazainak családja. Az $(S, \mathcal{I})$ pár teljesíti a függetlenségi axiómákat [5]. Az így kapott matroid az úgynevezett transzverzális matroid.

Kétdimenziós merevségi matroid Matroidok a merevségelméletben is fontos szerepet játszanak. Ha egy kétdimenziós rúd-csukló szerkezet merevségét szeretnénk meghatározni (generikus pozícióban lévő csuklók esetén), akkor ezt a rúdcsukló szerkezet által meghatározott gráf alapján megtehetjük. Egy egyszerü hurokmentes $G=(V, E)$ gráfot $(2,3)$-ritkának nevezünk, ha $i_{G}(X) \leq 2|X|-3$ minden $X \subseteq V$ halmazra, amire $|X| \geq 2$. Pollaczek-Geiringer [15] és Laman [13] tételei alapján $G$ pontosan akkor minimálisan merev, ha $(2,3)$-ritka és $|E|=2|V|-3$. A $(2,3)$-ritka gráfot alkotó élek halmazai a $G$ gráfban teljesítik a függetlenségi axiómákat $E$ alaphalmazon, így kapjuk az úgynevezett kétdimenziós merevségi matroidot. Részletes bevezetésért a kétdimenziós merevségi matroidhoz a merevség fogalmainak precíz definiálásával Jordán cikkét [9] javasoljuk. Meg kell jegyeznünk e ponton, hogy a merevségi matroid értelmezhető magasabb dimenziókban is, de ennek tárgyalása meghaladja e dolgozat kereteit.

\section{Ritkasági matroidok}

Legyen $G=(V, E)$ egy hurokmentes irányítatlan gráf, $k$ egy pozitív egész, míg $\ell \in \mathbb{Z}$ egy olyan egész szám, hogy $2 k>\ell$. Nevezzük $G$-t $(k, \ell)$-ritkának, 
ha $i_{G}(X) \leq k|X|-\ell$ minden $|X| \geq 2$ csúcshalmazra. Egy olyan $(k, \ell)$-ritka gráfot, amelyre $|E|=k|V|-\ell$, nevezzünk $(k, \ell)$-kritikusnak. Ezen megnevezések természetes módon halmazokra is értelmezhetők, vagyis egy $X \subseteq V$ halmaz $(k, \ell)$ kritikus a $G$ gráfon belül, ha $(k, \ell)$-ritka részgráfot feszít, és $i_{G}(X)=k|X|-\ell$.

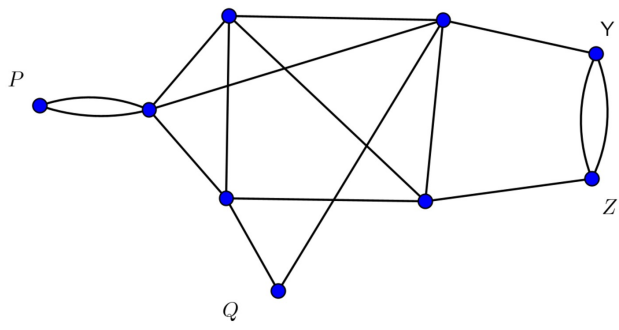

1. ábra. Egy $(2,2)$-kritikus gráf

2.1. Lemma. [10, Lemma 2.1] Legyen $G=(V, E)$ egy $(k, \ell)$-ritka gráf, és $T_{1}=\left(V_{1}, E_{1}\right)$ illetve $T_{2}=\left(V_{2}, E_{2}\right)$ legyen $G$ két $(k, \ell)$-kritikus részgráfja. Ha $\left|V_{1} \cap V_{2}\right| \geq 2$, akkor $T_{1} \cup T_{2}$ egy $(k, \ell)$-kritikus gráf.

Bizonyítás. Mivel $T_{1}$ és $T_{2}(k, \ell)$-kritikus, $i_{G}\left(V_{1} \cup V_{2}\right)+i_{G}\left(V_{1} \cap V_{2}\right) \geq i_{G}\left(V_{1}\right)+$ $i_{G}\left(V_{2}\right)=k\left|V_{1}\right|-\ell+k\left|V_{2}\right|-\ell=k\left|V_{1} \cup V_{2}\right|-\ell+k\left|V_{1} \cap V_{2}\right|-\ell$. Mivel viszont $G$ $(k, \ell)$-ritka, és $\left|V_{1} \cap V_{2}\right| \geq 2, k\left|V_{1} \cup V_{2}\right|-\ell+k\left|V_{1} \cap V_{2}\right|-\ell \geq i_{G}\left(V_{1} \cup V_{2}\right)+i_{G}\left(V_{1} \cap V_{2}\right)$, tehát egyenlőség áll fenn, vagyis $T_{1} \cup T_{2}$ (sőt, $T_{1} \cap T_{2}$ is) $(k, \ell)$-kritikus.

Ezen lemma segítségével be tudjuk bizonyítani, hogy a $(k, \ell)$-ritka élhalmazok egy valóban matroid független halmazait alkotják.

2.1. TÉTEL. Legyen $G=(V, E)$ egy hurokmentes irányítatlan gráf, $k \in \mathbb{Z}_{+}$, $\ell \in \mathbb{Z}$ és $2 k>\ell$. Legyen $\mathcal{F}=\{F \subseteq E \mid(V(F), F)(k, \ell)$-ritka gráfot alkot $\}$. Ekkor az $(E, \mathcal{F})$ pár matroidot alkot.

Bizonyítás. Vegyük észre, hogy az $\mathcal{F}$ halmazai automatikusan teljesítik az A1) és A2) axiómákat. Az A3') axiómát fogjuk bizonyítani. Legyen $E_{1}$ és $E_{2}$ két $(k, \ell)$-ritka élhalmaza $G$-nek úgy, hogy $\left|E_{1}\right|<\left|E_{2}\right|$. Tegyük fel, hogy nincsen olyan $e \in E_{2}-E_{1}$, amire $E_{1} \cup\{e\}$ ritka. Ekkor minden $e \in E_{2}-E_{1}$ élre létezik egy maximális $C_{e} \subseteq E_{1}$ élhalmaz, amelyre $\left(V\left(C_{e}\right), C_{e}\right)$ ( $\left.k, \ell\right)$-kritikus részgráfot alkot és $V\left(C_{e}\right)$ feszíti $e$-t. Vegyük a $\mathcal{C}=\left\{C_{e} \mid e \in E_{2}-E_{1}\right\}$ halmazt. Mivel $C_{e^{-t}}$ maximálisnak választottuk, az 2.1. Lemma alapján $\left|V\left(C^{\prime}\right) \cap V\left(C^{\prime \prime}\right)\right| \leq 1$ bármely két különböző $C^{\prime}, C^{\prime \prime} \in \mathcal{C}$ halmazra. (Az lehet, hogy $C_{e}=C_{f}$ némely $e, f \in E_{2}-E_{1}$-re, de ez nem jelent problémát.) Legyen $E^{\prime}=\left\{e \mid e \in E_{1} \cap E_{2}\right.$, és $e \notin C$ tetszőleges $C \in \mathcal{C}$ esetén $\}$. Így $E_{2}-E^{\prime}$ éleit pontosan egy $V(C)$ halmaz 
feszíti, ahol $C \in \mathcal{C}$, továbbá $E_{2}$ ritkasága miatt $i_{E_{1}}(V(C)) \geq i_{E_{2}}(V(C))$ minden $C \in \mathcal{C}$-re. $\left|E_{2}\right|=\left|E^{\prime}\right|+\sum_{C \in \mathcal{C}} i_{E_{2}}(V(C)) \leq\left|E^{\prime}\right|+\sum_{C \in \mathcal{C}} i_{E_{1}}(V(C)) \leq\left|E_{1}\right|$, ami ellentmond az $\left|E_{1}\right|<\left|E_{2}\right|$ feltételnek, tehát létezik olyan $e \in E_{2}-E_{1}$, amire $E_{1} \cup\{e\}$ ritka. Ezzel beláttuk az A1), A2) és A3') axiómákat, vagyis a $(k, \ell)$-ritka élhalmazok tényleg matroidot alkotnak $E$-n, mint alaphalmazon.

Vegyük észre, hogy a bevezetőben látott grafikus matroid egy $(k, \ell)$-ritkasági matroid a $(k, \ell)=(1,1)$ értékekre (ezt nevezzük $(1,1)$-ritkasági matroidnak). Valóban, az (1,1)-ritka halmazok pontosan a körmentes részgráfok $G$-ben, vagyis pontosan a grafikus matroid független halmazai.

Tekintsük most az $(1,1)$-ritkasági matroid helyett a $(k, k)$-ritkasági matroidot. Egy $G=(V, E)$ gráf esetén a ritkaság azt jelenti, hogy minden $\emptyset \neq X \subseteq V$ halmazra $i_{G}(X) \leq k(|X|-1)$ (ha $|X|=1$, akkor mivel $G$ nem tartalmaz hurokélet, $\left.i_{G}(X)=0=k(|X|-1)\right)$. Egy $(k, k)$-kritikus gráf $(k, k)$-ritka és $|E|=k(|V|-1)$. Ez nyilván teljesül minden olyan gráfra, amelyik $k$ diszjunkt feszítőfa uniója, de Nash-Williams ismert eredménye alapján [14] csak ezekre, vagyis a $(k, k)$-kritikus gráfok pontosan $k$ diszjunkt feszítőfa uniójából állnak. (Ilyen például az 1. ábrán bemutatott $(2,2)$-kritikus gráf is, amely könnyen ellenőrizhetően két feszítőfa uniója.)

Látható, hogy a bevezetőben definiált kétdimenziós merevségi matroid pontosan a (2,3)-ritkasági matroidnak felel meg. Így például, ha minimális költségü merev részgráfját keressük egy merev gráfnak két dimenzióban, akkor azt mohó módon megtehetjük. Erre fokszámkorlátos irányítások segítségével $O\left(|V|^{2}\right)$ algoritmus ismert [1].

\subsection{Hipergráfok}

Az ilyen módon bevezetett ritkasági matroidokat könnyen általánosíthatjuk, ha gráfok helyett hipergráfokra értelmezzük őket. Legyen $\mathcal{H}=(V, \mathcal{E})$ egy hipergráf a $V$ csúcshalmazon és az $\mathcal{E}$ hiperéleken. Legyen $k \in \mathbb{Z}_{+}, \ell \in \mathbb{Z}$ és $2 k>\ell$. Nevezzünk egy hipergráfot $(k, \ell)$-ritkának, ha $i_{\mathcal{H}}(X) \leq k|X|-\ell$ minden olyan $X \subseteq V$ halmazra, amely legalább egy hiperélet feszít (egy halmaz akkor feszít egy hiperélet, ha annak minden csúcsa a halmazban van). Egy olyan $(k, \ell)$-ritka hipergráfot, amelyre $|\mathcal{E}|=k|V|-\ell$ nevezzünk $(k, \ell)$-kritikusnak. Tetszőleges $\mathcal{H}$ hipergráf esetén a $(k, \ell)$-ritka hiperél halmazok teljesítik a függetlenségi axiómákat, így azok az $\mathcal{E}$ alaphalmazon matroidot alkotnak [5].

Tekintsük most a transzverzális matroidot. Egy $G=(S, T, E)$ páros gráfot a következő hipergráffal reprezentálhatunk: Legyen $V=T$ és $s$ szomszédjai alkossanak egy hiperélet minden $s \in S$-re. Így tehát a hiperélek az $S$ ponthalmaz szomszédainak feleltethetők meg, vagyis bijekció áll fenn a hiperélek és az $S$ pontjai között is. Hall tétele alapján egy $S^{\prime} \subseteq S$ ponthalmaz pontosan akkor párosítható, ha minden $S^{\prime \prime} \subseteq S^{\prime}$ halmazra $\left|S^{\prime \prime}\right| \leq\left|N_{G}\left(S^{\prime \prime}\right)\right|$, ahol $N_{G}(X)$ az $X$ csúcshalmaz szomszédainak halmazát jelöli. Ez a hipergráfos megfogalmazásban 
azt jelenti, hogy az $S^{\prime}$ hiperél-halmazra teljesül az (1,0)-ritkasági feltétel. Vagyis a transzverzális matroid megfeleltethető egy $(1,0)$-ritkasági matroidnak a megfelelő hipergráfon.

\section{2. ( $m, \ell)$-ritkasági matroid}

A $(k, \ell)$-ritkaság egy másik általánosítását kapjuk, ha a $k$ konstans helyett egy függvényt vezetünk be a csúcsokon. Legyen $m: V \rightarrow \mathbb{Z}_{+}$egy nemnegatív, egészértékü függvény a $G=(V, E)$ gráf csúcsain és $\ell \in \mathbb{Z}$ egész szám. Legyen tetszőleges $X \subseteq V$ halmazra $\widetilde{m}(X)=\sum_{x \in X} m(x)$. Nevezzünk egy gráfot $(m, \ell)$ ritkának, ha $i_{G}(X) \leq \widetilde{m}(X)-\ell$ minden $|X| \geq 2$ halmazra. Egy olyan $(m, \ell)$-ritka gráfot, amelyre $|E|=\widetilde{m}(V)-\ell$ nevezzünk $(m, \ell)$-kritikusnak. Az 2.1. Lemma könnyen látható módon átvihetö $(k, \ell)$-kritikus helyett $(m, \ell)$-kritikus részgráfokra is, és így látható, hogy az 2.1. Tétel bizonyítása érvényes marad, tehát az $(m, \ell)$ ritka élhalmazok matroidot alkotnak. $[5]$.

Megjegyezzük, hogy az $(m, \ell)$-ritkasági matroid is értelmezhető hipergráfokra

\section{Ritkasági matroidok redundáns növelése}

Egy $(k, \ell)$-kritikus gráf olyan szempontból minimálisnak tekinthetö, hogy tetszőleges élét elhagyva már olyan gráfot kapunk, amely nem tartalmaz $(k, \ell)$-kritikus részgráfot. Néhány esetben arra lehet szükség a rendszer hibatürő képességének fokozása érdekében, hogy egy él kiesése után is maradjon egy $(k, \ell)$-kritikus részgráf. Például a bevezetésben már említett 2-élösszefüggőség ilyen, hiszen egy 2élösszefüggő gráf tetszőleges élét elhagyva a megmaradt gráf tartalmaz még feszítőfát. Egy másik motiváció lehet a merevségelmélet, ahol egy szerkezet merevségét biztosítandó szeretnénk, ha egy tetszőleges él törlésével is merev maradna a gráfunk. A következő elnevezéseket szintén a merevségelméletbeli alkalmazások motiválják.

Egy $G=(V, E)$ gráfot $(k, \ell)$-merevnek hívunk, ha tartalmaz feszítő $(k, \ell)$ kritikus részgráfot. Egy gráfot $(k, \ell)$-redundánsnak nevezünk, ha tetszőleges élét elhagyva $(k, \ell)$-merev gráfot kapunk.

Vizsgáljuk most a következő kérdést:

1. Probléma. Adott egy $G=(V, E)(k, \ell)$-merev gráf. Határozzunk meg egy olyan minimális elemszámú $F$ élhalmazt, amelyre $G+F(k, \ell)$-redundáns gráfot eredményez.

A probléma egy könnyebben vizsgálható változatában feltesszük a $G$ gráfról, hogy nemcsak $(k, \ell)$-merev, hanem minimálisan $(k, \ell)$-merev, vagyis $(k, \ell)$-kritikus 
is. Az eredeti 1. Problémára fogunk az általános problémaként hivatkozni, míg ezt a változatot megszorított problémának nevezzük.

Az általános, illetve a megszorított problémát számos $(k, \ell)$ párra vizsgálták már, kezdve az $(1,1)$-merev gráfok redundánssá növelésével, amelyet Eswaran és Tarjan oldott meg 1976-ban [4]. Az általános problémára tetszóleges $(k, k)$ érték esetén Frank és Király T. adott megoldást [6], míg a (2,3)-kritikus gráfok növelését García és Tejel vizsgálta [7]. Az általános probléma vizsgálatát Király Cs. és Mihálykó végezte el [10]. Ez utóbbi cikket követve vázoljuk fel az eredményeket.

\section{1. $(k, \ell)$-kritikus gráfok növelése}

Először vizsgáljuk meg a megszorított problémát. Adott egy $G=(V, E)(k, \ell)$ kritikus gráf, célunk egy minimális elemszámú $F$ élhalmaz megtalálása, amire $G+$ $F(k, \ell)$-redundáns. Ha a kontextusból egyértelmü, a továbbiakban elhagyjuk a $(k, \ell)$ előtagot a ritka, kritikus, merev és redundáns jelzők elől. Egy tetszőleges $F^{\prime}$ élhalmazra, amire $G+F^{\prime}$ redundáns, minden $f \in F^{\prime}$ élre $f$ néhány élét redundánssá teszi, jelölje ezek halmazát $T(f)$. Mivel $T(f)+f$ egy kört alkot a ritkasági matroidban, könnyü belátni a következő lemmát.

3.1. Lemma. [10, Lemma 2.3] Legyen $G=(V, E)$ egy $(k, \ell)$-kritikus gráf és $i, j \in V$ két csúcs. Ekkor $T(i j)=\{\bigcap T \mid T \subseteq G$ kritikus, és $i, j \in V(T)\}$.

Jelölje $R\left(F^{*}\right) G$ redundáns éleit $G+F^{*}$-ban. Vegyük észre, hogy $T(f)=$ $R(\{f\})$. Az első lényeges megfigyelés ezt terjeszti ki nagyobb halmazokra:

3.2. Lemma. [10, Lemma 2.4] $R\left(\left\{f_{1} \cup \cdots \cup f_{k}\right\}\right)=T\left(f_{1}\right) \cup \cdots \cup T\left(f_{k}\right)$

Így tehát minden $e \in E$ élre létezik egy olyan $f \in F^{\prime}$, amire $e \in T(f)$. Vagyis nem létezhet olyan $G^{\prime} \subsetneq G$ kritikus részgráf, amely $F^{\prime}$ minden élét feszíti, mert akkor a 3.1. és 3.2. Lemma miatt $F^{\prime}$ csak $G^{\prime}$ éleit feszítené, $G-G^{\prime}$ éleit nem, ellentmondva a $G+F^{\prime}$ redundánsságának.

Nevezzünk egy $C \subsetneq V$ halmazt ko-kritikusnak, ha $V-C$ egy kritikus részgráfot feszít. Ekvivalensen $C(k, \ell)$-ko-kritikus halmaz, ha $1 \leq|C| \leq|V|-2$ és összesen $k|C|$ élnek van legalább egyik végpontja $C$-ben. Ha $C$ ko-kritikus, akkor egy $F^{\prime}$ élhalmazra, amelyre $G+F^{\prime}$ redundáns, $C \cap V\left(F^{\prime}\right) \neq \emptyset$. Így tehát a következő egyenlőtlenség fennáll.

3.3. Lemma. Legyen $G$ egy $(k, \ell)$-kritikus gráf legalább 4 csúcson. Ekkor

$\min \{|F|: F$ egy élhalmaz, amire $G+F(k, \ell)$-redundáns $\} \geq$
$\geq \max \left\{\left\lceil\frac{|\mathcal{C}|}{2}\right\rceil: \mathcal{C}\right.$ páronként diszjunkt $(k, \ell)$-ko-kritikus halmazok családja $\}$. 
Maximum három csúcs esetén az 1. Probléma megoldása tetszőleges $(k, \ell)$ esetén könnyen kiszámítható, így ezen gráfokkal nem foglalkozunk.

Állítjuk, hogy az előző egyenlőtlenség helyén valójában egyetlen kivételtől eltekintve egyenlőség áll. Az ehhez vezető lépések vázolásához először vizsgáljuk meg a ko-kritikus halmazok strukúráját.

Jelölje $\mathcal{C}^{*}$ a tartalmazásra nézve minimális ko-kritikus halmazokat $G$-ben. (Természetesen feltehetjük, hogy a 3.3. Lemmában $\mathcal{C} \operatorname{csak} \mathcal{C}^{*}$-beli halmazokból áll. Például az 1. ábrán a tartalmazásra nézve minimális ko-kritikus halmazok $\{P\},\{Q\}$ és $\{Y, Z\}$.)

3.4. Lemma. [10, Theorem 5.5] $\mathcal{C}^{*}$ halmazai páronként diszjunktak, vagy található olyan $i, j \in V$ csúcspár, amire $\{i, j\} \cap C \neq \emptyset$ minden $C \in \mathcal{C}^{*}$ ko-kritikus halmazra.

Könnyü bizonyítani, hogy ha nincsen ko-kritikus halmaz $G$-ben, akkor tetszőleges $i j$ élre $G+i j$ redundáns lesz. Ez az egyetlen kivétel, amikor nem áll egyenlöség a 3.3. Lemmában. Hasonlóképpen egyszerü belátni, hogy ha van legalább egy kokritikus halmaz, és létezik 3.4. Lemmában leírt $i, j \in V$ pontpár, vagyis amire $\{i, j\} \cap C \neq \emptyset$ minden $C \in \mathcal{C}^{*}$ ko-kritikus halmazra, akkor $G+i j$ redundáns [10]. Tehát feltehetjük, hogy $\mathcal{C}^{*}$ halmazai páronként diszjunktak és $\left|\mathcal{C}^{*}\right| \geq 3$.

Így könnyen vehetünk egy $X \subset V$ halmazt, amire $|C \cap X|=1$ minden $C \in \mathcal{C}^{*}$ ko-kritikus halmazra. Belátható, hogy egy olyan $F^{\prime}$ élhalmazra az $X$ halmazon, amelyre $\left(X, F^{\prime}\right)$ összefüggő gráfot alkot, $G+F^{\prime}$ redundáns gráfot eredményez (lásd [10, Lemma 5.8]). Így már találtunk egy $\left|\mathcal{C}^{*}\right|-1$ méretü élhalmazt, amely redundánssá növeli $G$-t. Mivel $\left|\mathcal{C}^{*}\right|-1$ megegyezik $\left[\frac{\left|\mathcal{C}^{*}\right|}{2}\right]$-vel, ha $\left|\mathcal{C}^{*}\right|=3$, így $\left|\mathcal{C}^{*}\right| \leq 3$ esetre az egyenlőséget tudjuk bizonyítani a 3.3. Lemmában. (Így az 1. ábra gráfját optimálisan redundánssá tudjuk növelni, például egy $F=\{P Y, Y Q\}$ élhalmazzal.)

Feltehetjük most, hogy van legalább négy diszjunkt ko-kritikus halmaz $G$-ben.

3.5. Lemma. [10, Lemma 5.9] Legyen $G=(V, E)$ egy $(k, \ell)$-kritikus gráf, és legyenek $x_{1}, x_{2}, x_{3}, y \in V$ csúcsok $G$ négy diszjunkt ko-kritikus halmazából. Ekkor, ha $T^{*}=T\left(y x_{1}\right) \cup T\left(y x_{2}\right) \cup T\left(y x_{3}\right)$, akkor $T^{*}=T\left(y x_{1}\right) \cup T\left(x_{2} x_{3}\right)$, vagy $T^{*}=T\left(y x_{2}\right) \cup T\left(x_{1} x_{3}\right)$.

A 3.5. Lemma ötlete megjelenik már García és Tejel munkájában is ([7, Lemma 15]). Ök mutattak rá arra is, hogyan használhatjuk ki ezt a tulajdonságot. Vegyük az $X$ csúcshalmazt, és jelöljünk ki egy $y \in X$ csúcsot. Legyen $H=\{y x \mid x \in X-\{y\}\}$ élhalmaz. Tudjuk, hogy mivel $H$ egy összefüggő gráfot alkot $X$-en, $G+H$ redundáns. Ekkor addig, amíg $y$ fokszáma $H$-ban legalább három, alkalmazhatjuk a 3.5. Lemma lépését, hogy két élet egy élre cseréljünk, úgy, hogy a kapott $H^{\prime}$ élhalmazra $G+H^{\prime}$ továbbra is redundáns. A végül kapott $H^{*}$ élhalmazra igaz, hogy minden csúcs fokszáma $H$-ra nézve legfeljebb egy, kivéve $y$-t, ami legfeljebb kettő, és $G+H^{*}$ redundáns. Így $F=H^{*}$ egy pontosan $\left\lceil\frac{\left|\mathcal{C}^{*}\right|}{2}\right\rceil$ 
elemszámú élhalmaz, ami redundánssá növeli $G$-t. Így beláthatjuk a következő tételt.

3.1. TÉTEL. [10, Theorem 5.1] Legyen $G$ egy $(k, \ell)$-kritikus gráf. Ekkor vagy $G$-ben nincsenek $(k, \ell)$-ko-kritikus halmazok, és ekkor tetszőleges $i, j \in V$-re $G+i j$ $(k, \ell)$-redundáns, vagy a következő egyenlöség áll:

$\min \{|F|: F$ egy élhalmaz, amire $G+F(k, \ell)$-redundáns $\}=$
$=\max \left\{\left\lceil\frac{|\mathcal{C}|}{2}\right\rceil: \mathcal{C}\right.$ páronként diszjunkt $(k, \ell)$-ko-kritikus halmazok családja $\}$.

\section{2. $(k, \ell)$-merev gráfok növelése}

Vizsgáljuk meg most azt az esetet, ha a bemeneti $G=(V, E)$ gráf nem $(k, \ell)$ kritikus, hanem $(k, \ell)$-merev, vagyis az általános 1 . Problémát. Ha a $(k, \ell)=(1,1)$ példánál maradunk, ez megfelel annak, hogy nem egy fát, hanem egy összefüggő gráfot akarunk 2-élösszefüggővé növelni. Ebben az esetben a 2-élösszefüggő komponensek összehúzásával egy fát kapunk, amelyet optimálisan 2-élösszefüggővé növelve egy olyan élhalmazt kapunk, amely az eredeti gráfot optimálisan növeli 2-élösszefüggővé. Ezen ötlet általánosítható minden $\ell \leq k$ párra. Első ránézésre talán meglepő módon, egyéb értékekre vannak nehézségi eredmények. García és Tejel bizonyította [7], hogy (2,3)-merev gráf növelése redundánssá $N P$-nehéz, majd az ő módszerüket általánosítva Király és Mihálykó bizonyította, hogy minden $k<\ell$ értékre $(k, \ell)$-merev gráf növelése redundánsra nemcsak, hogy NP-nehéz, de már konstans faktorú közelítést adni rá is lehetetlen, ha $P \neq N P$ [10].

Az összehúzás általánosításához szükség van az $(m, \ell)$-ritkasági matroidokra. Természetesen minden $(k, \ell)$-ritkasági matroid egyben $(m, \ell)$-ritkasági matroid is az $m \equiv k$ függvényre.

Ha $\ell \leq k$, az 2.1. Lemma egy általánosítása alapján (lásd [10, Lemma 2.1]) $G$ minden tartalmazásra nézve maximálisan merev részgráfja, így maximális redundáns részgráfjai is csúcsdiszjunktak. Legyen $\ell^{\prime}=\max (\ell, 0)$. Húzzuk össze $G$ tartalmazásra nézve maximális redundáns részgráfjait, és definiáljunk egy $m$ függvényt az így kapott $G^{\prime}$ gráf csúcsain. Az $m$ függvény legyen a következő: $G$ összehúzott pontjaira legyen $m:=\ell^{\prime}$, míg miden egyéb pontra legyen $m:=k$. Bizonyítható, hogy $G^{\prime}\left(m, \ell^{\prime}\right)$-kritikus [10, Section 3].

3.2. TÉTEL. [10, Theorem 3.3] Legyen $G$ egy $(k, \ell)$-merev gráf $\ell \leq k$ értékekre. Ekkor $G$ optimálisan redundánssá növelhetö azzal az élhalmazzal, amely az összehúzások után kapott $\left(m, \ell^{\prime}\right)$-kritikus $G^{\prime}$ gráfot $\left(m, \ell^{\prime}\right)$-redundánssá növeli.

Mivel a 3.1. Tétel általánosabb formában is igaz, ha $(k, l)$-kritikus gráfok helyett olyan $\left(m, \ell^{\prime}\right)$-kritikus gráfokra tekintjük, amelyet az előbbi módon kaptunk (lásd [10, Theorem 5.1]), kijelenthetjük, hogy az általános probléma is megoldható, ha $\ell \leq k$. 
Ezen eredmények az $(k, \ell)$-merev, illetve a $(k, \ell)$-kritikus gráfon könnyen általánosíthatók hipergráfokra is.

\subsection{Algoritmikus eredmények}

Mint a ritkasági matroidok bevezetésénél említettük, egy $(2,3)$-merev gráf egy minimális merev részgráfját $O\left(|V|^{2}\right)$ időben megtalálhatjuk [1]. Ezt egy fokszámkorlátos irányításokat használó algoritmus segítségével érhetjük el, mely algoritmus egy függetlenségi orákulumot ad, amely egy új e élről tudja meghatározni, hogy egy már kiválasztott, egyelőre ritka $F$ élhalmazhoz hozzávéve az így kapott $F+e$ élhalmaz ritka-e. Az algoritmus előnye, hogy ha $F+e$ nem ritka, meghatározza a legszükebb kritikus halmazt, ami miatt nem ritka - vagyis pontosan $T_{F}(e)$-t. Ez az algoritmus tetszőleges $(k, \ell)$ értékre is végrehajtható $O\left(|V|^{2}\right)$ időben, sőt, $(m, \ell)$ kritikus gráfok esetén is $O\left(|V|^{2} m^{*}\right)$ időben, ahol $m^{*}$ az $m$ függvény értékének maximuma [5].

Így a redundáns növelési feladat optimálisan megoldható polinomiális időben. Ugyanis polinomiális időben megtalálhatjuk a redundáns éleket, és $\left(m, \ell^{\prime}\right)$-kritikus gráf esetén $T(e)$-t is meg tudjuk határozni tetszőleges $e$ élre. A minimális kokritikus halmazok meghatározását az segíti, hogy komplementerük $G$ tartalmazásra nézve maximális kritikus részgráfját feszíti [10]. Így a 3.1. alfejezetben definiált $X$ halmaz is megtalálható polinomiális időben. Ha $|X|<4$, akkor $G$ maximum 2 éllel redundánssá tehető, ami polinomiális időben könnyen megoldható. Ha $|X| \geq 4$, a 3.5. Lemma algoritmusát végrehajtva polinomiális időben kaphatunk egy optimális élhalmazt.

Megemlítjük, hogy mind az általános, mind a megszorított redundáns növelési probléma megoldható $O\left(|V|^{2}\right)$ időben egy bonyolultabb algoritmussal, amely mélyebben kihasználja az $(m, \ell)$-ko-kritikus halmazok struktúráját [10].

\section{Nyitott kérdések}

Láttuk, hogy ritkasági matroidok több helyen használhatók, és megismertünk egy olyan eredményt, ahol ténylegesen ki lehetett használni a struktúrájukat egy probléma optimális megoldásához. Most két olyan fontos nyitott kérdést vázolunk fel, amelyre a speciális esetekben ismert válasz talán reményt adhat, hogy más $(k, \ell)$ értékekre is megoldhatóak.

\subsection{Ritka gráfok redundánssá növelése}

Egy természetesen adódó kérdés az 1 . Probléma megoldása után, hogyan lehet $G$-t redundánsan merevvé növelni, ha $G$ nem $(k, \ell)$-merev, hanem $(k, \ell)$-ritka.

2. Probléma. Legyen $G$ egy $(k, \ell)$-ritka gráf. Határozzunk meg egy minimális 
elemszámú $F$ élhalmazt, amire $G+F(k, \ell)$-redundáns.

Vegyük észre, hogy ha $(k, \ell)$-redundáns helyett $(k, \ell)$-merevet kérdeznénk, a válasz azonnal következne a matroid tulajdonságból.

Ha (1,1)-redundánsságot vizsgáljuk, akkor egy erdőt kell 2-élösszefüggővé növelni minimális számú él hozzáadásával, amely könnyen megoldható. Frank és Király megmutatta, hogy a 2 . Probléma megoldható $(k, k)$-ritka gráfok esetén is [6]. Megoldásuk - melyben tetszőleges gráfot növeltek $(k, k)$-redundánssá - a poliéderes kombinatorika mély eredményeire támaszkodott, így érdekes lehetne erre is egy könnyebben átlátható megoldás. Általános $(k, \ell)$ párokra egyelőre pozitív eredmény nem ismert.

\subsection{Minimális vágás}

Az eddigi kérdésekkel szemben most nem az a célunk, hogyan lehet egy gráfot még „biztonságosabbá” tenni, hanem próbáljuk meg „tönkretenni”.

3. Probléma. Legyen $G=(V, E)$ egy $(k, \ell)$-merev gráf. Találjunk egy olyan minimális elemszámú $E^{\prime} \subset E$ élhalmazát, amelyet törölve $G$-ből, $G-E^{\prime}$ már nem $(k, \ell)$-merev.

Vegyük észre, hogy az $(1,1)$ esetben ez pontosan a minimális vágás feladat. Ezért nevezzük a 3. Problémát minimális vágás feladatnak ritkasági matroidokban. Ez a minimális vágás feladat megjelenik az Egres Open Problems [3] között, a feladat részletes leírásával és az eddig elért részeredményekkel, illetve azokról szóló diszkusszióval. Közismert, hogy a minimális vágás (1,1)-merev gráfok esetén polinomiálisan megoldható. Király ezt a hipergrafikus matroidra általánosította [11], amely az (1,1)-ritkasági matroid hipergráfokon. Sőt, a feladat transzverzális matroidra, vagyis az (1,0)-hipergrafikus matroidra is megoldható - a megoldás minimális számú csúcs törlése az $S$ halmazból, hogy csökkenjen a párosítás mérete. A merevségelmélet szempontjából érdekes, továbbra is nyitott kérdés viszont a $(2,3)$-merev gráfok minimális vágása.

\section{Köszönetnyilvánítás}

A projekt az Európai Unió támogatásával, az Európai Szociális Alap társfinanszírozásával valósult meg (EFOP-3.6.3-VEKOP-16-2017-00002). A szerző hálás Jordán Tibornak a kézirattal kapcsolatos sok hasznos észrevételéért. 


\section{Hivatkozások}

[1] A.R. Berg AND T. Jordán: Algorithms for graph rigidity and scene analysis. In G. Di Battisa and U. Zwick, szerk., Algorithms - ESA 2003, Lecture Notes in Computer Science, Springer, Vol. 2832, pp. 78-89 (2003). DOI: 10.1007/978-3-540-39658-1_10

[2] J. EDmonds: Submodular functions, matroids, and certain polyhedra. In R. Guy, H. Hanani, N. Sauer, and J. Schönheim, szerk., Combinatorial Structures and their Applications. Gordon and Breach, New York (1970). DOI: 10.1007/3-540-36478-1_2

[3] EGRES: Egres open problems. lemon.cs.elte.hu/egres/open/Destroying_rigidity

[4] K.P. Eswaran and R.E. TARJan: Augmentation problems. SIAM Journal on Computing, Vol. 5 No. 4, pp. 653-665 (1976). DOI: 10.1137/0205044

[5] A. Frank: Connections in Combinatorial Optimization. Oxford University Press (2011). DOI: $10.1016 /$ j.dam.2011.09.003

[6] A. Frank and T. KirÁly: Combined connectivity augmentation and orientation problems. Discrete Appl. Math., Vol. 131 No. 2, pp. 401-419 (2003).

DOI: $10.1016 / \mathrm{S} 0166-218 \mathrm{X}(02) 00460-2$

[7] A. García and J. Tejel: Augmenting the rigidity of a graph in $\mathbb{R}^{2}$. Algorithmica, Vol. 59 No. 2, pp. 145-168 (2011). DOI: 10.1007/s00453-009-9300-9

[8] R. Ikeshita And S. Tanigawa: Count matroids of group-labeled graphs. Combinatorica, Vol. 38 No. 5, pp. 1101-1127 (2018). DOI: 10.1007/s00493-016-3469-8

[9] T. Jordán: Combinatorial rigidity: Graphs and matroids in the theory of rigid frameworks. In Discrete Geometric Analysis, volume 34 of MSJ Memoirs, Mathematical Society of Japan, Japan, pp. 33-112 (2016). DOI: 10.2969/msjmemoirs/03401C020

[10] Cs. KirÁly AND A. MinÁLykó: Sparse graphs and an augmentation problem. Technical Report TR-2020-06, Egerváry Research Group, Budapest (2020). Revision 1 of TR 2019-14. www.cs.elte.hu/egres

[11] T. KIRÁLY: Computing the minimum cut in hypergraphic matroids. Technical Report (Quick Proof) QP-2009-05, Egerváry Research Group, Budapest (2009).

[12] M. LoREA: On matroidal families, Discrete Mathematics, Vol. 28 No. 1, pp. 103-106 (1979) DOI: $10.1016 / 0012-365 X(79) 90190-0$

[13] G. Laman: On graphs and rigidity of plane skeletal structures. Journal of Engineering Mathematics, Vol. 4, pp. 331-340 (1970). DOI: 10.1007/BF01534980

[14] C.St.J.A. Nash-Williams: Edge-disjoint spanning trees of finite graphs. Journal of the London Mathematical Society, Vol. 36, pp. 445-450 (1961). DOI: 10.1112/jlms/s1-36.1.445

[15] H. Pollaczek-Geiringer: Über die Gliederung ebener Fachwerke. ZAMM - Journal of Applied Mathematics and Mechanics, Vol. 7 No. 1, pp. 58-72 (1927).

DOI: 10.1002/zamm.19270070107

[16] S. Tanigawa: Matroids of gain graphs in applied discrete geometry. Transactions of the American Mathematical Society, Vol. 367, pp. 8597-8641 (2012). DOI: 10.1090/tran/6401

[17] W. Whiteley: Some matroids from discrete applied geometry. In J.E. Bonin, J.G. Oxley, and B. Servatius, szerk., Matroid Theory, Contemporary Mathematics, AMS, Vol. 197, pp. 171-311 (1996). DOI: 10.1090/conm/197/02540

[18] T. Zaslavsky: Biased graphs II. The three matroids. Journal of Combinatorial Theory, Series B, Vol. 51 No. 1, pp. 46-72 (1991). DOI: 10.1016/0095-8956(91)90005-5 


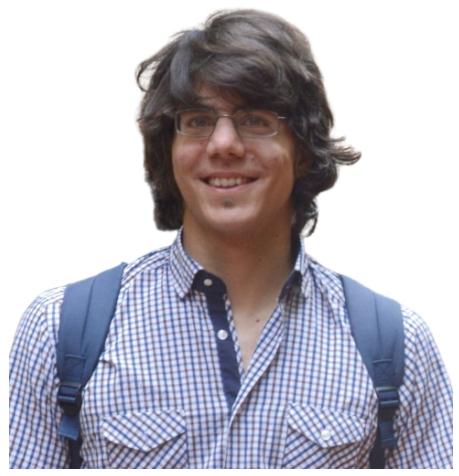

Mihálykó András 1992-ben született Veszprémben. BSc és MSc tanulmányait az ELTE Matematika szakán végezte. MSc diplomája után egy évet programozó/kutatóként dolgozott a SignAll cégnél, ahol automatikus jelnyelvi fordítást fejlesztett. 2018-ban felvételt nyert az ELTE Matematika doktori iskolájába, Jordán Tibor témavezetésével. Témája kombinatorikus merevségelmélet, kifejezetten redundánsan és globálisan merevvé növelö algoritmusokban ért el új eredményeket. 2021-ben az EPFL Lausanne vendég doktori hallgatója lett.

\section{MIHÁLYKÓ ANDRÁS}

Eötvös Loránd Tudományegyetem, Operációkutatási Tanszék, mihalyko@cs.elte.hu

\section{ABOUT COUNT MATROIDS}

\section{ANDRÁs MihÁLYKó}

We call a graph $G=(V, E)(k, \ell)$-sparse if $i_{G}(X) \leq k|X|-\ell$ holds for every vertex set, where $|X| \geq 2$ and $i_{G}(X)$ denotes the number of edges in $G$ spanned by $X$. These sparsity conditions provide a matroid on $E$, if $k \in \mathbb{Z}_{+}$and $\ell<2 k$ integer. These are the so-called count matroids. Count matroids occur in several applications in combinatorial optimization. For example, in spanning trees, matchings or in rigidity theory. Our goal is to introduce the count matroids from their definition through well known and new results, including the redundant augmentation problem for count matroids up to open problems. 